\title{
Potential Ecological Risk and Health Risk Assessment of Heavy Metals and Metalloid in Soil around Xunyang Mining Areas
}

\author{
Na Wang ${ }^{1,2,3}$, Jichang Han ${ }^{1,2,3, *}$, Yang Wei ${ }^{1,2,3}$, Gang $\mathrm{Li}^{1,2,3}$ and Yingying Sun ${ }^{1,2,3}$ \\ 1 Shaanxi Provincial Land Engineering Construction Group Co., Ltd., Xi'an 710075, China \\ 2 Institute of Land Engineering and Technology, Shaanxi Provincial Land Engineering Construction Group \\ Co., Ltd., Xi'an 710075, China \\ 3 Key Laboratory of Degraded and Unused Land Consolidation Engineering, the Ministry of Natural \\ Resources of China, Xi' an 710075, China \\ * Correspondence: hanjc_sxdj@126.com; Tel.: +86-029-88489545
}

Received: 8 July 2019; Accepted: 24 August 2019; Published: 4 September 2019

\begin{abstract}
Xunyang is rich in various metal minerals and is one of the four major metal mining areas in Shaanxi province, China. To explore the effects of soil heavy metals and metalloid pollution on the environment and human health around the mining areas, four places-Donghecun (D), Gongguan $(G)$, Qingtonggou $(\mathrm{Q})$ and Nanshagou $(\mathrm{N})$ - were selected as the sampling sites. Potential ecological risk (PER) and health risk assessment (HRA) models were used to analyze the environmental and health risks around the mining areas. The concentration of heavy metals $(\mathrm{Cd}, \mathrm{Cr}, \mathrm{Pb}, \mathrm{Zn}, \mathrm{Ni}, \mathrm{Cu}, \mathrm{Hg})$ and metalloid (As) in cultivated land in the vicinity of Xunyang mining areas indicated that, except for $\mathrm{Cu}$, the remaining elements detected exceeded the threshold values at some sites. The geo-accumulation index $\left(I_{G e o}\right)$ revealed that soils in $\mathrm{G}$ and $\mathrm{Q}$ could be identified as being extremely contaminated. PER indicated that there was significantly high risk at $\mathrm{G}$ and $\mathrm{Q}$ for $\mathrm{Hg}$. In $\mathrm{N}, \mathrm{Pb}$ recorded the highest $E_{r}^{i}$, which also demonstrates a considerable pre-existing risk. HRA indicated that the hazard index (HI) for both carcinogenic and non-carcinogenic risks was much higher among children than among adults, and the ingestion pathway contributed the greatest risk to human health, followed by the dermal pathway and inhalation. Because the $\mathrm{HI}$ values of the metals and metalloid in the study areas were all lower than 1 , there was no significant non-carcinogenic risk. However, the carcinogenic risk for $\mathrm{Cr}$ is relatively higher, surpassing the tolerable values in $\mathrm{G}, \mathrm{Q}$, and $\mathrm{N}$. This study analyzed the ecological risks and human health risks of heavy metals and metalloid in farmland soils near the sampling mining areas, and demonstrated the importance of environmental changes caused by land development in the mining industry.
\end{abstract}

Keywords: Xunyang mining area; heavy metals; potential ecological risk assessment; health risk assessment

\section{Introduction}

Heavy metals and metalloid are considered to be the most dangerous contaminants to the environment on account of their toxicity to the soil, and they reduce the sustainability of the environment [1]. According to the National Soil Bulletin Survey in 2014, soil pollution caused by heavy metals and metalloid is prevalent in China, and the soil quality of cultivated land has been gradually decreasing [2]. The national total soil over-standard rate is $16.1 \%$. One investigation showed that the content of inorganic pollutants such as $\mathrm{Cd}, \mathrm{Hg}$, $\mathrm{As}$ and $\mathrm{Pb}$ has been gradually increasing [3]. However, due to the scarcity of cultivated land in China, contaminated arable land is still employed for agricultural production [4]. Human activities make an important contribution to environmental pollution; studies have shown that the pollution of arable land mainly comes from industrial production, 
agricultural activities and mineral exploitation. Among these, mineral mining is one of the chief factors leading to the heavy metals and metalloid pollution of agricultural land [5,6]. Large amounts of acid wastewater and tailing slag are produced during the mineral development process, and it has become a bottleneck that restricts the mineral development industry $[7,8]$. Toxic heavy metals and metalloid produced during the ore mining, transportation, smelting and tailings storage processes potentially permeate into the soil by means of the atmosphere, surface water, etc. Furthermore, the toxic materials retain, migrate, accumulate, and are enriched by the crops [9]. In addition, e-waste, traditional medicines, and industrial emissions are major sources of $\mathrm{Pb}$ exposure in China [10]. Metalloid is also one of the pollution sources, and they cover pathogenesis, dust storms, volcanic eruptions, geothermal/hydrothermal activity, and forest fires [11]. The constant accumulation of heavy metals in the soil has a negative impact on the ecosystem, owing to the fact that they can be migrated from the soil to crops and food, seriously endangering the safety of human beings around the mining areas [12,13]. It has been discovered that people exposed to environments containing $\mathrm{Cd}$ have an increased potential for diseases such as kidney dysfunction, as well as a high risk of bone fractures [14]. A long-term exposure to $\mathrm{Pb}$ during pregnancy may cause some fetal nerve system development disorders, because $\mathrm{Pb}$ can be transferred from the bones of pregnant women to the fetus at a rapid rate $[15,16]$. This continues throughout the baby's lifetime [17]. Additionally, Pb affects several key organ systems within the human body, including the cardiovascular system $[18,19]$, renal system $[20,21]$ and hepatic system $[19,22]$. Fetuses are also at a very high risk of neurotoxins from $\mathrm{Hg}$ [23].

Soils in the vicinity of mining areas are most likely polluted by wastewater and tailings from the smelter in mining regions. Numerous studies of soil heavy metals and metalloid pollution related to mining activities in 2005-2012 have been carried out in China [24], and these have shown that metals in mining areas are likely, for the most part, to exceed the standards. Wu et al. [25] pointed out that, compared to their relative backgrounds, the concentrations of $\mathrm{Hg}$ and $\mathrm{Pb}$ in the Xiaoqinling gold mining region were at high risk. Li et al. [26] indicated that the average concentrations of As, $\mathrm{Pb}, \mathrm{Cd}, \mathrm{Cu}, \mathrm{Zn}$ in the soil in the vicinity of the mining region exceeded the limit values. In addition, Zhao et al. [27] also revealed that the respective concentrations of $\mathrm{Pb}, \mathrm{Zn}$ and $\mathrm{Mn}$ around the tailings were higher than the tolerance limits values of Inner Mongolia. Xunyang is one of the largest mining areas in Shaanxi province, and the mining activities are a source of $\mathrm{Hg}$ in the environment surrounding the mine [28]. Previous studies have shown that vegetation planted by local residents is seriously polluted. The riparian soils and sediments in the Xunyang $\mathrm{Hg}$ mining area were found to be seriously contaminated by $\mathrm{Hg}[28,29]$. Even so, only very limited research has been conducted evaluating the health risks (carcinogenic and non-carcinogenic) and ecological risks in these regions. Therefore, this paper makes two major contributions. The first is the assessment of the degree of contamination with heavy metals and metalloid in the farmland surrounding the four major mining sites. The second is the estimation of the potential influence on risks to the environment, as well as risks (carcinogenic and non-carcinogenic) to human health.

\section{Materials and Methods}

\section{Sample Collection and Analysis}

Sampling of surface soils was collected from Xunyang county, located between E $108^{\circ} 58^{\prime}-109^{\circ} 48^{\prime}$ and N $32^{\circ} 29^{\prime}-33^{\circ} 13^{\prime}$ in southwest part of Shaanxi province. This region is rich of more than 39 kinds of mineral resources. The total storage of $\mathrm{Au}$ in $\mathrm{D}$ had reached $50 \mathrm{t}$, the total $\mathrm{Pb}-\mathrm{Zn}$ in $\mathrm{N}$ had reached 940000t. And the total storage of $\mathrm{Hg}$ in $\mathrm{G}$ and Q had reached 12715t, which made the county known as "the Hg capital of the world". The soil collection work was carried out in November 2017. Based on the "Technical Specifications for Soil Environmental Monitoring", surface soil $(0-20 \mathrm{~cm})$ was collected at the four sampling points in D, G, Q and N respectively. The sampling point in the Xunyang County is presented in Figure 1. At each sampling point 5 samples were gathered using an "S" sampling step and then combined to form an individual composite sample. In total, twenty-four surface soil samples 
were collected. The samples were stored in ziplock bags with labels and then brought back to the lab. The sampling process were repeated 3 times at each sampling point. The soil samples should be air-dried under natural conditions to avoid external interference, and they were ground and sieved through a $0.15 \mathrm{~mm}$ sieve to be evenly mixed for the later use [30].

The test method of heavy metals and metalloid in soil samples is described as follow: Before using ICP-MS (Agilent 7700), the soils need to be completely decomposed. Digestion methods according to US EPA method 3050B with $\mathrm{HNO}_{3}-\mathrm{H}_{2} \mathrm{O}_{2}-\mathrm{HCl}$ [31] with the ratio of 3:1 (hydrochloric and nitric acids) for the heavy metal extraction. About $0.1000 \mathrm{~g}$ of soil sample is collected in the digestion tube, and hold overnight. The samples were digested at the temperature of $40^{\circ} \mathrm{C}, 80^{\circ} \mathrm{C}, 120^{\circ} \mathrm{C}$ and $140{ }^{\circ} \mathrm{C}$ for $1 \mathrm{~h}$, respectively. After cooling, the supernatant is filtered through a 0.45 micron filter to centrifuge tube for the further analysis [32,33]. The concentration of $\mathrm{Hg}$ was digested by $\mathrm{HNO}_{3}-\mathrm{H}_{2} \mathrm{SO}_{4}$. After that, atomic fluorescence Spectrometry (AFS-9760) at $253.65 \mathrm{~nm}$ was used for the measurement [34,35]. The study used standard reference material (GSS-8, GSS-10 and GSF-3) to assure the quality control. These materials are from the National Center for Standard Materials in China. The ratio of recoveries ranged between $90 \%$ and $110 \%$ for the elements throughout this study.

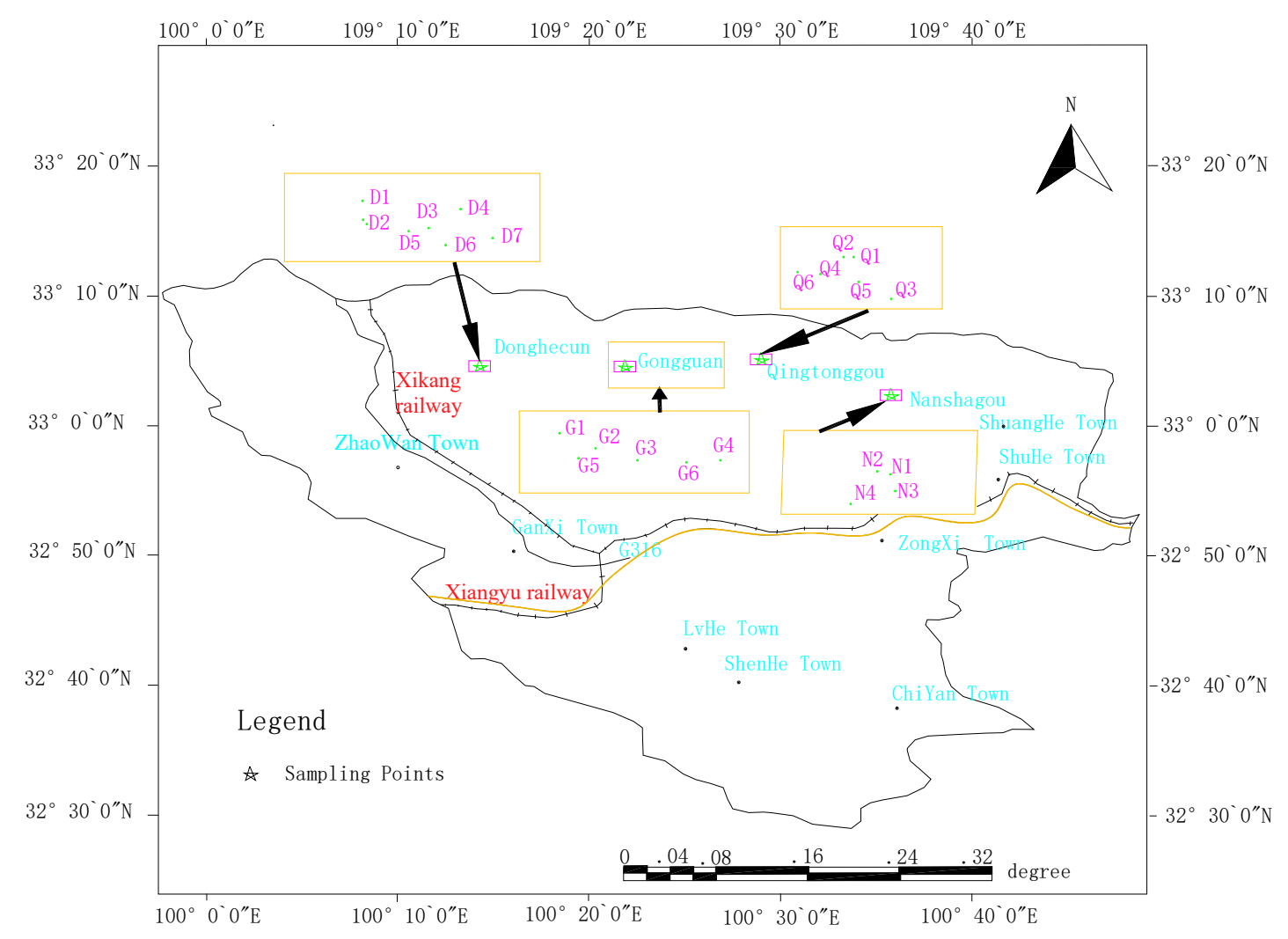

Figure 1. Map of sampling sites of Xunyang.

\section{Evaluation Method}

\subsection{Ecological Risk Assessment Model}

The geo accumulation index evaluation method is a quantitative index for the study of pollutant contamination in water environment sediments by Muller. Its expression is shown in (1):

$$
I_{G e o}=\log _{2}\left(\frac{C_{i}}{k B_{i}}\right)
$$


In this expression, $C_{i}$ stands for the observed value of heavy metal $i, \mathrm{mg} / \mathrm{kg}$; $B_{i}$ is the natural background value of heavy metals and metalloid in Shaanxi province, and $k$ is the conversion coefficient, which is 1.5. According to the magnitude of the value, heavy metals and metalloid degrees are sorted at 7 levels, as given in Table 1.

Table 1. Geochemical index classification.

\begin{tabular}{cccc}
\hline$I_{G e o}$ & Classification & $I_{G e o}$ & Classification \\
\hline$I_{G e o}<0$ & Uncontaminated & $2 \leq I_{G e o}<3$ & Moderately to strongly contaminated \\
\hline $0 \leq I_{G e o}<1$ & $\begin{array}{c}\text { Uncontaminated to moderately } \\
\text { contaminated }\end{array}$ & $3 \leq I_{G e o}<4$ & Strongly contaminated \\
\hline $1 \leq I_{G e o}<2$ & Moderately contaminated & $4 \leq I_{G e o}<5$ & Strongly to extremely contaminated \\
\hline$I_{G e o} \geq 6$ & Extremely contaminated & & \\
\hline
\end{tabular}

In 1980, Swedish scientist Hakanson is the first one to use PER index [36]. Because there are some different types of toxicity among metal elements, and the sensitivities of heavy metals and metalloid to the environment, the PER index is usually calculated using the concentration value of heavy metals and metalloid [37]. It more accurately represents the impact of heavy metals and metalloid on the ecological environment. The expressions are as follow (2)-(4):

$$
\begin{gathered}
C_{f}^{i}=\frac{c_{s}^{i}}{c_{n}^{i}} \\
E_{r}^{i}=T_{r}^{i} \times C_{f}^{i} \\
R I=\sum_{i=1}^{n} E_{r}^{i}
\end{gathered}
$$

Among them, $R I$ is calculated as the sum of $E_{r}^{i}$, which represents the PER index; $E_{r}^{i}$ is the PER index for single element pollution; $c_{n}^{i}$ is the background value of soil heavy metals and metalloid in Shaanxi Province; $c_{s}^{i}$ is the tested values of elements in soils, $\mathrm{mg} / \mathrm{kg} ; T_{r}^{i}$ is the toxicity response coefficient of heavy metals and metalloid. Environmental background values and toxicity response coefficients are shown in Table 2. The classification results of the PER index are shown in Table 3.

Table 2. Environmental background values and toxic-response parameters of heavy metals in the soils.

\begin{tabular}{ccccccccc}
\hline Element & $\mathbf{C d}$ & $\mathbf{C r}$ & $\mathbf{H g}$ & $\mathbf{A s}$ & $\mathbf{P b}$ & $\mathbf{C u}$ & $\mathbf{Z n}$ & $\mathbf{N i}$ \\
\hline$c_{n}^{i}(\mathrm{mg} / \mathrm{kg})$ & 0.76 & 62.5 & 0.063 & 11.1 & 21.4 & 21.4 & 69.4 & 28.8 \\
$T_{r}^{i}$ & 30 & 2 & 40 & 10 & 5 & 5 & 1 & 5 \\
\hline
\end{tabular}

Table 3. Classification of potential ecological risk coefficient $\left(E_{r}^{i}\right)$ and risk index (RI).

\begin{tabular}{cccccc}
\hline $\begin{array}{c}\text { Ecological } \\
\text { Risk }\end{array}$ & Low Risk(A) & Moderate Risk (B) & $\begin{array}{c}\text { Considerable } \\
\text { Risk (C) }\end{array}$ & High Risk(D) & $\begin{array}{c}\text { Significantly } \\
\text { High Risk (E) }\end{array}$ \\
\hline$E_{r}^{i}$ & $<40$ & $40-80$ & $80-160$ & $160-320$ & $>320$ \\
RI & $<150$ & $150-300$ & $300-600$ & $\geq 600$ & - \\
\hline
\end{tabular}

\subsection{Health Risk Assessment Model}

The effect of heavy metals and metalloid on human health is the result of a combination of various elements. Therefore, the hazard index (HI) is applied to comprehensively evaluate the health risks to humans. There are three major ways for human exposure, namely oral ingestion, respiratory inhalation and dermal contact [38]. HRA includes hazard identification, exposure assessment, dose response 
assessment and risk characterization [38]. In general, the above-mentioned three exposures can be estimated by the average daily dose (CID) on both children and adults. The formulas are as following (5)-(7):

$$
\begin{gathered}
C I D_{\text {ingest }}=\frac{C \times I n g R \times E F \times E D}{B W \times A T} \times 10^{-6} \\
C I D_{\text {inhale }}=\frac{C \times I n h R \times E F \times E D}{P E F \times B W \times A T} \times 10^{-6} \\
C I D_{\text {dermal }}=\frac{C \times S A \times S L \times A B F \times E F \times E D}{B W \times A T} \times 10^{-6}
\end{gathered}
$$

Among them, $C$ is the measured content of heavy metals and metalloid of the sample $(\mathrm{mg} / \mathrm{kg})$; $\operatorname{Ing} R$ is the daily intake (mg/day); $\operatorname{InhR}$ is the rate of daily inhalation; $E F$ is the exposure frequency for contact with assessed soils (days/year); $E D$ refers to exposure duration (years); $B W$ means average weight of human body $(\mathrm{kg}) ; A T$ is the average time (days); $P E F$ is the release factor of particles $\left(\mathrm{m}^{3} / \mathrm{kg}\right) ; S A$ is the exposure area $\left(\mathrm{cm}^{2}\right) ; S L$ is a skin adhesion factor; $A B F$ is a skin adsorption factor. Exposure parameters for the HRA are shown in Table 4.

Table 4. Exposure parameters for the health risk assessment.

\begin{tabular}{cccc}
\hline \multirow{2}{*}{ Parameter } & \multirow{2}{*}{ Company } & \multicolumn{2}{c}{ Value } \\
\cline { 3 - 4 } & & Children & Adult \\
\hline IngR & $\mathrm{mg} / \mathrm{d}$ & 200 & 100 \\
$E F$ & $\mathrm{~d} /$ year & 350 & 350 \\
$E D$ & years & 6 & 25 \\
$B W$ & $\mathrm{~kg}$ & 15.9 & 56.8 \\
$A T$ & $\mathrm{days}$ & 26,280 & 9125 \\
$I n h R$ & $\mathrm{~m}^{3} / \mathrm{d}$ & 7.5 & 14.5 \\
$P E F$ & $\mathrm{~m}^{3} / \mathrm{kg}$ & $1.36 \times 10^{9}$ & $1.36 \times 10^{9}$ \\
$S A$ & $\mathrm{~cm}^{2}$ & 2800 & 5700 \\
$S L$ & $\mathrm{mg}^{2} \mathrm{~cm}^{2}$ & 0.2 & 0.07 \\
$A B F$ & none & 0.001 & 0.01 \\
\hline
\end{tabular}

HRA [39] is mainly a process of analyzing and predicting the possible adverse effects of environmental pollutants on human health, including two different risk models: carcinogenic risk and non-carcinogenic risk. The formulas for calculating the carcinogenic and non-carcinogenic effects of each heavy metal exposure pathway are listed on (8) and (9):

$$
\begin{gathered}
H Q=\frac{C I D}{R f D} \\
H I=\sum H Q=H Q_{i n g}+H Q_{i n h}+H Q_{\text {dermal }}
\end{gathered}
$$

According to US EPA [40], RfD in the equation refers to the reference dose for HRA calculation, and the values of $R f D$ for each element are different. If the $H I$ value is lower than 1 , there will be no significant risk of non-carcinogenic effects. However, if the $H I$ value exceeds $1(H I>1)$, there will be occurring non-carcinogenic risk effects with the rise of $H I$ value [41].

Using the surface soil heavy metals and metalloid concentration to calculate the health risk may result in a rise in daily chronic intake, which may lead to an overestimation of the health hazard index, as expounded earlier. Hence, the bioavailable concentrations of metals were adopted to estimate HRA by Yuswir et al. [42]. 
The cancer risk LCR is applied for characterize the health risks of carcinogenic for heavy metals and metalloid. This is determined by the sum of each exposure route. In line with US EPA [40] the CSF values of $\mathrm{Cd}, \mathrm{Cr}, \mathrm{Pb}$ and As are 6.3, 0.5, 0.0085 and $1.5 \mathrm{mg} / \mathrm{kg} /$ day, the acceptable value for cancer risk is less than $1.0 \times 10^{-4}$, and the tolerable of LCR value is between $1.0 \times 10^{-6}$ and $1.0 \times 10^{-4}$ according to the US Environmental Protection Agency [41]. Reference dose for non-carcinogenic metals and slope factors for carcinogenic metals are shown in Table 5.

$$
\begin{gathered}
C R=C D I \times C S F \\
\sum C R=L C R=C R_{\text {ing }}+C R_{\text {inh }}+C R_{\text {derm }}
\end{gathered}
$$

Table 5. Reference dose for non-carcinogenic metals and slope factors for carcinogenic metals.

\begin{tabular}{cccc}
\hline \multirow{2}{*}{ Elements } & \multicolumn{3}{c}{ RfD (mg.(kg.d) $^{-\mathbf{1}}$ ) } \\
\cline { 2 - 4 } & Intake & Inhalation & Skin Contact \\
\hline $\mathrm{Cd}$ & $1.00 \times 10^{-3}$ & $1.00 \times 10^{-5}$ & $1.00 \times 10^{-5}$ \\
$\mathrm{~Pb}$ & $3.50 \times 10^{-3}$ & $3.52 \times 10^{-3}$ & $5.25 \times 10^{-4}$ \\
$\mathrm{Cr}$ & $3.00 \times 10^{-3}$ & $2.86 \times 10^{-5}$ & $6.00 \times 10^{-5}$ \\
$\mathrm{Ni}$ & $2.00 \times 10^{-2}$ & $2.06 \times 10^{-2}$ & $5.40 \times 10^{-3}$ \\
$\mathrm{Cu}$ & $4.00 \times 10^{-2}$ & $4.02 \times 10^{-3}$ & $1.20 \times 10^{-2}$ \\
$\mathrm{Zn}$ & $3.00 \times 10^{-1}$ & $3.00 \times 10^{-1}$ & $6.00 \times 10^{-2}$ \\
$\mathrm{Hg}$ & $3.00 \times 10^{-4}$ & $8.57 \times 10^{-5}$ & $2.10 \times 10^{-5}$ \\
$\mathrm{As}$ & $3.00 \times 10^{-4}$ & $1.23 \times 10^{-4}$ & $1.23 \times 10^{-4}$ \\
\hline
\end{tabular}

\section{Results and Discussions}

\subsection{The Concentration of Heavy Metal}

Figure 2 presents the total concentration of heavy metals and metalloid at the four mining areas. The total concentration of heavy metals and metalloid showed in a wide range. According to the corresponding Grade II of national environmental quality standard, $\mathrm{Cr}$ and $\mathrm{Ni}$ in study areas are all higher than the corresponding standard except in D. The mean values of $C d$ in $D, G, Q$ and $N$ were $105,380,539,381 \mathrm{mg} / \mathrm{kg}$. Cu content in four study areas are all under the corresponding standard. However the concentration of Cd in D, G, Q and N is 3.02, 2.52, 2.65, 4.90 times greater than the Grade II standard value. The concentration of $\mathrm{Zn}$ and As in four areas varied tremendously. Compared to other sites, the average concentration of $\mathrm{Zn}$ in N surpassed the standard value with the number of $327 \mathrm{mg} / \mathrm{kg}$, As in D surpassed the standard value with the number of $72 \mathrm{mg} / \mathrm{kg}$. Concentration of $\mathrm{Pb}$ in $\mathrm{N}$ is higher than those in D, G and $\mathrm{Q}$, and exceeds the standard value. The highest mean concentration of $\mathrm{Hg}$ was observed in $Q$ with the value of $3.93 \mathrm{mg} / \mathrm{kg}$, followed in $\mathrm{G}$ with the mean value of $3.86 \mathrm{mg} / \mathrm{kg}$.

Based on the above analysis, most of the heavy metals posed a high pollution to the arable land around the mining areas. As it is shown from the samples collected from $\mathrm{D}$, the soil is mainly contaminated by As and Cd. Studies shown that metalloid As exists in most ore bodies and may be released during crustal movement [1,43]. For other regions, $\mathrm{G}$ and $\mathrm{Q}$ mining areas were mainly contaminated by $\mathrm{Cr}, \mathrm{Ni}, \mathrm{Cd}$ and $\mathrm{Hg}$; sampling close to $\mathrm{Pb}-\mathrm{Zn}$ mining area is polluted by $\mathrm{Cr}, \mathrm{Ni}, \mathrm{Zn}$, $\mathrm{Cd}$ and $\mathrm{Pb}$ (Figure 2). Figure 2 also shows that, although the average concentration of some heavy metals and metalloid is lower than standard value, the max concentrations were high. 

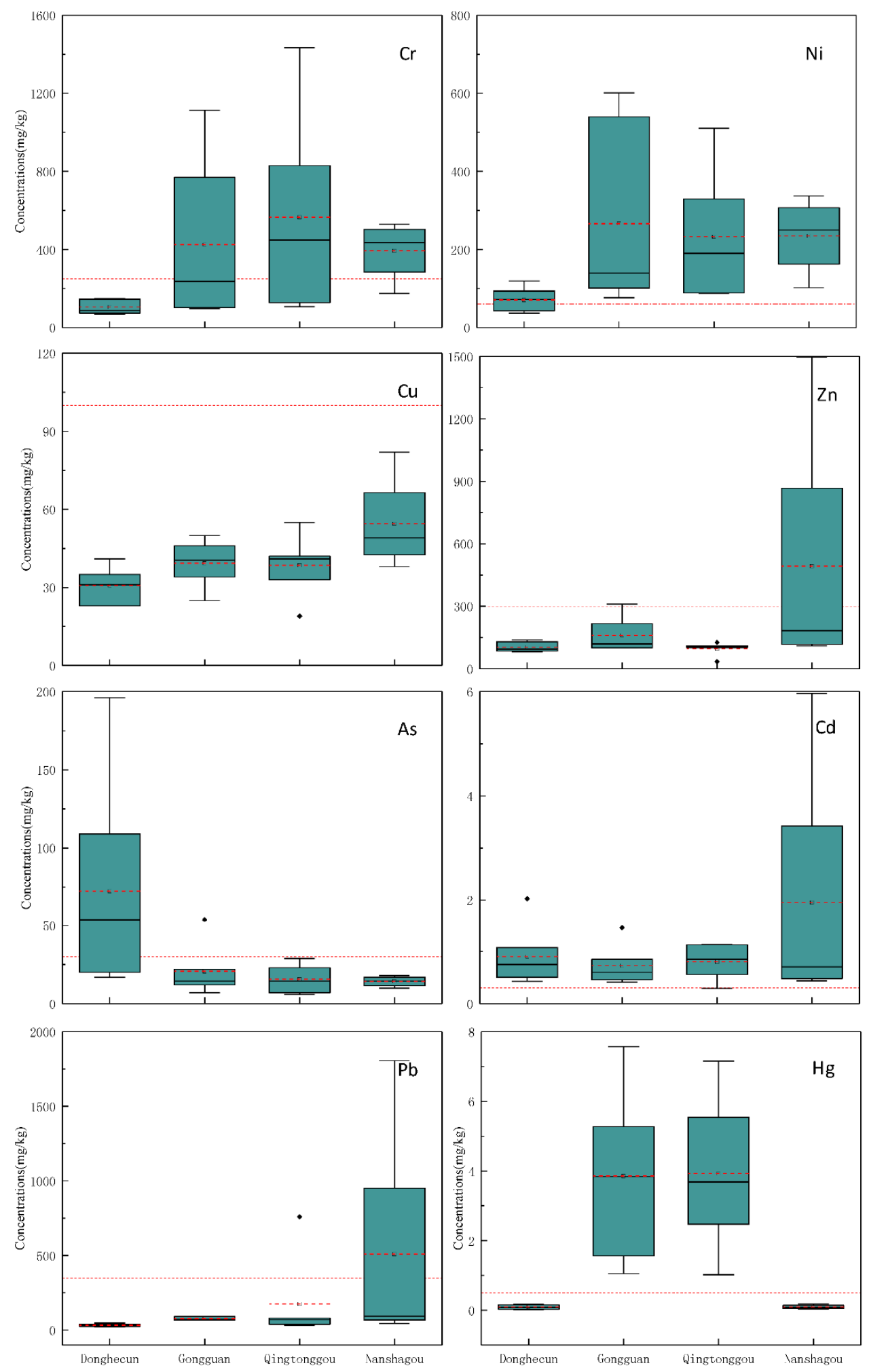

Figure 2. The concentration of heavy metals in sampling sites.

\subsection{Geo-Accumulation Index $\left(I_{G e o}\right)$}

Heavy metal contamination is usually assessed by the enrichment factor [44]. The $I_{G e o}$ values demonstrated that the mining areas were polluted with $\mathrm{As}, \mathrm{Hg}, \mathrm{Ni}, \mathrm{Pb}, \mathrm{Cd}$, and $\mathrm{Cr}$ (Figure 3). It is demonstrated that As in $\mathrm{D}$ is classified of having moderate to strong contamination with the value of 2.11. Other elements such as $\mathrm{Cu}, \mathrm{Zn}, \mathrm{Cd}$ and $\mathrm{Hg}$ are classified as uncontaminated in D according 
to Table 1 . However $\mathrm{Cr}, \mathrm{Ni}$ in $\mathrm{G}, \mathrm{Q}$, and $\mathrm{N}$ were classified as moderately to strongly contaminated. Meanwhile, $\mathrm{Pb}$ in $\mathrm{G}$ and $\mathrm{Zn}$ in $\mathrm{N}$ were categorized moderately contaminated. Among all sampling sites, $\mathrm{Hg}$ in $\mathrm{G}$ and $\mathrm{Q}$ posed an extreme contamination with the values of 5.35 and 5.38. The $I_{G e o}$ values at $\mathrm{G}$ and $\mathrm{Q}$ decreased as the sequence of $\mathrm{Hg}>\mathrm{Ni}>\mathrm{Cr}>\mathrm{Pb}>\mathrm{As}>\mathrm{Zn}>\mathrm{Cu}>\mathrm{Cd}$.

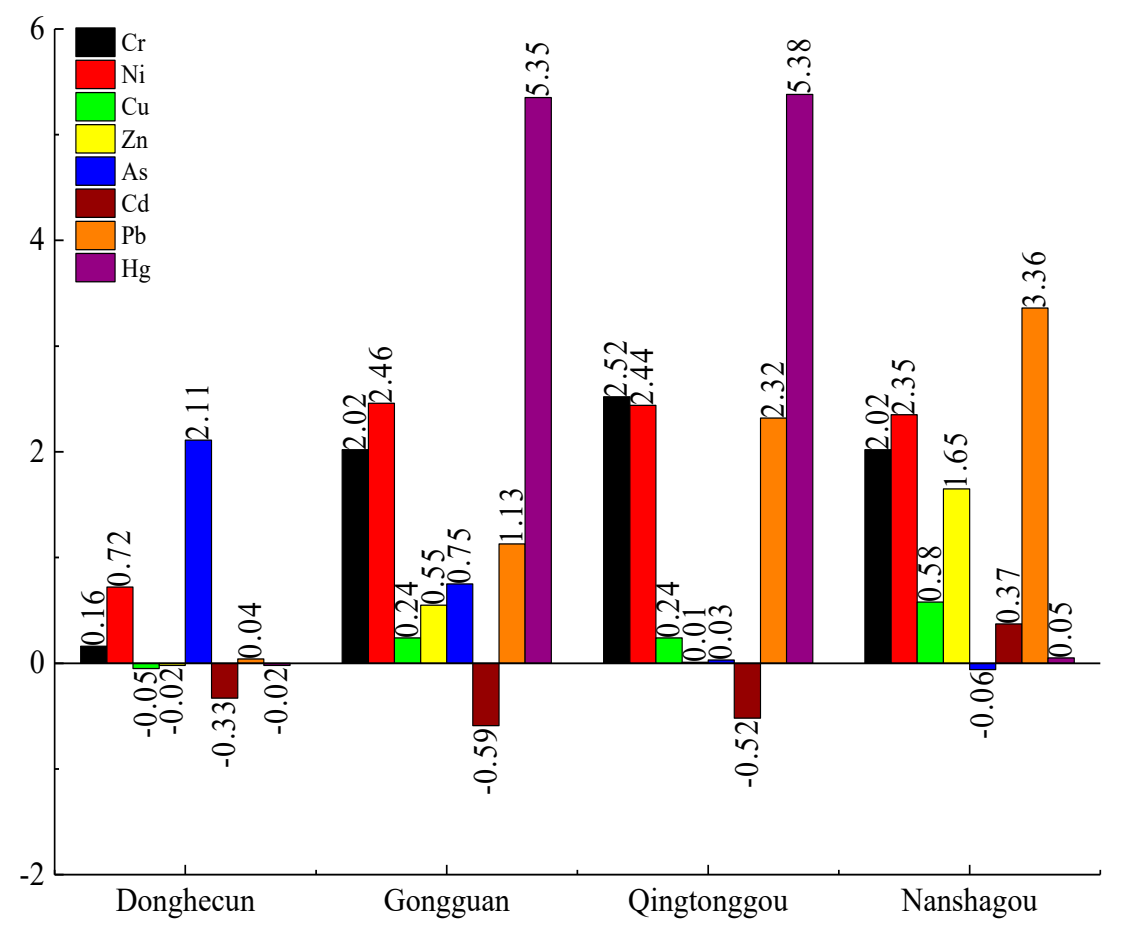

Figure 3. $I_{G e o}$ distribution of heavy metals in Xunyang mining area.

\subsection{Potential Ecological Risk Index}

It is shown in Table 6, The values of $E_{r}^{i}$ of $\mathrm{Cr}, \mathrm{Cu}$ and $\mathrm{Zn}$ in all sites were much less than 40, indicating a low ecological risk (Table 3). The PER factors of $\mathrm{Ni}\left(E_{r}^{i}\right)$ in $\mathrm{G}$ and $\mathrm{Q}$ were greater than 40 but lower than 80, showing a moderate risk. The PER factors of $\mathrm{Cd}$ and $\mathrm{Pb}\left(E_{r}^{i}\right)$ in $\mathrm{N}$, and As in $\mathrm{D}$ are also of moderate risk with the value of 58.07, 77.03 and 64.86. Throughout the entire study areas, $E_{r}^{i}$ values of $\mathrm{Hg}$ are higher than 40 in $\mathrm{G}$ and Q. PER index of $\mathrm{Hg}$ reached the max, which identifies a significant risk of $\mathrm{Hg}$ in the mercury mining areas. This result might be the fact that $\mathrm{Hg}$ vapor permeates the soil through atmospheric deposition, causing serious $\mathrm{Hg}$ pollution in the soil near the $\mathrm{Hg}$ mine [45]. Additionally, $\mathrm{Hg}$ might get into the soils by waste water from the mining district [46].

The values of $E_{r}^{i}$ by metal elements to the total RI are illustrated in Figure 4. It is shown that the $\mathrm{RI}$ in the study area is between 134.54 and 2667.19. The highest RI found at $\mathrm{Q}$ with the value of 2667.19, followed by the value in $\mathrm{G}$ with the number of 2576.80 . The results indicate a significantly high risk according to the risk classification (Table 3). The contributions of $\mathrm{Hg}$ in $\mathrm{Q}$ and $\mathrm{G}$ to $\mathrm{RI}$ are $93.5 \%$ and $95.1 \%$ respectively. Relatively speaking, the RI in D is at low risk, compared to other elements $\mathrm{Hg}$ and As, which leads a moderate risk. The contributions of $\mathrm{Hg}$ and As to RI are $43.89 \%$ and $42.21 \%$. The RI in $\mathrm{N}$ was higher than 300 , but lower than 600 , showing a considerable risk. The contributions of $\mathrm{Cd}$, $\mathrm{Pb}, \mathrm{Hg}$ to $\mathrm{RI}$ are $17.04 \%, 22.60 \%, 18.26 \%$ respectively. Despite this, the RI values demonstrated a low ecological risk in D. 
Table 6. Potential ecological risk index for heavy metals.

\begin{tabular}{cccccc}
\hline \multicolumn{2}{c}{ Site } & D & G & Q & N \\
\hline \multirow{2}{*}{$\mathrm{Cr}$} & $E_{r}^{i}$ & 3.36 & 12.16 & 17.25 & 12.19 \\
& Level & $\mathrm{A}$ & $\mathrm{A}$ & $\mathrm{A}$ & $\mathrm{A}$ \\
\hline \multirow{2}{*}{$\mathrm{Ni}$} & $E_{r}^{i}$ & 12.33 & 41.32 & 40.63 & 38.37 \\
& Level & $\mathrm{A}$ & $\mathrm{B}$ & $\mathrm{B}$ & $\mathrm{A}$ \\
\hline \multirow{2}{*}{$\mathrm{Cu}$} & $E_{r}^{i}$ & 7.24 & 8.88 & 8.88 & 11.21 \\
& Level & $\mathrm{A}$ & $\mathrm{A}$ & $\mathrm{A}$ & $\mathrm{A}$ \\
\hline \multirow{2}{*}{$\mathrm{Zn}$} & $E_{r}^{i}$ & 1.48 & 2.19 & 1.51 & 4.71 \\
& Level & $\mathrm{A}$ & $\mathrm{A}$ & $\mathrm{A}$ & $\mathrm{A}$ \\
\hline \multirow{2}{*}{$\mathrm{Cd}$} & $E_{r}^{i}$ & 35.72 & 29.84 & 31.42 & 58.07 \\
& Level & $\mathrm{A}$ & $\mathrm{A}$ & $\mathrm{A}$ & $\mathrm{B}$ \\
\hline \multirow{2}{*}{$\mathrm{Pb}$} & $E_{r}^{i}$ & 7.68 & 16.45 & 37.4 & 77.03 \\
& Level & $\mathrm{A}$ & $\mathrm{A}$ & $\mathrm{A}$ & $\mathrm{B}$ \\
\hline \multirow{2}{*}{$\mathrm{As}$} & $E_{r}^{i}$ & 64.86 & 25.23 & 15.32 & 14.41 \\
& Level & $\mathrm{B}$ & $\mathrm{A}$ & $\mathrm{A}$ & $\mathrm{A}$ \\
\hline \multirow{2}{*}{$\mathrm{Hg}$} & $E_{r}^{i}$ & 59.05 & 2449.52 & 2492.7 & 62.22 \\
& Level & $\mathrm{B}$ & $\mathrm{E}$ & $\mathrm{E}$ & $\mathrm{B}$ \\
\hline \multirow{2}{*}{$\mathrm{RI}$} & 134.54 & 2576.80 & 2667.19 & 340.83 \\
\hline & & & & &
\end{tabular}

Previous studies have suggested [47] that tailings contain a large amount of toxic heavy metals such as $\mathrm{Cd}, \mathrm{Pb}, \mathrm{Cu}, \mathrm{Ni}$ and $\mathrm{Zn}$. These toxic heavy metals are released into the environment by weathering in the form of oxides or sulfides. Soils near mining operations pose potential health risks [48], for which activities of smelter lead to the pollution of $\mathrm{Cd}$, and its toxicity is the greatest compared to other elements [49]. In N, Cd presents the moderate risk $\left(E_{r}^{i}\right)$ with the value of 58.07, which contributes $17.0 \%$ to total RI, and Cd in G is the lowest with the value of 29.84 (1.2\% contribution).

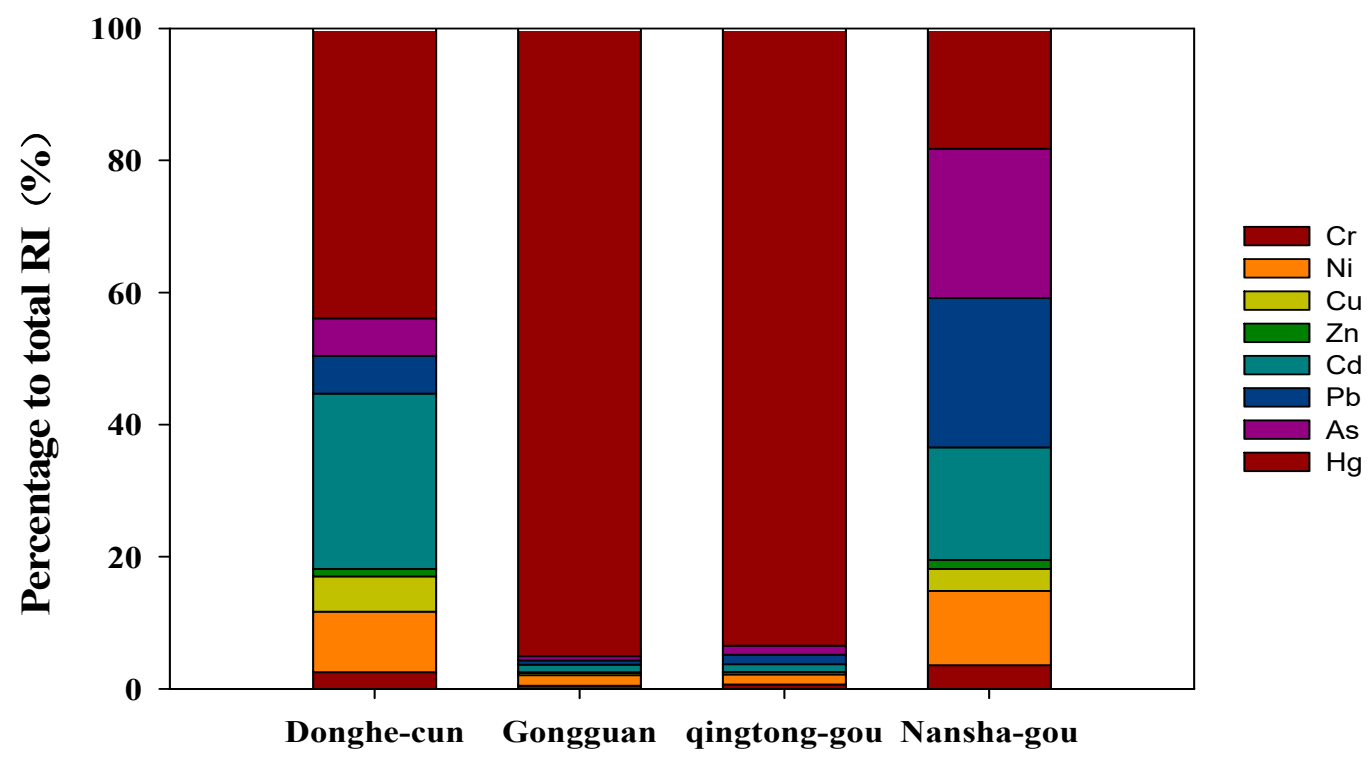

\section{Sampling location}

Figure 4. Percentage of potential ecological risk index for single heavy metals to total RI.

\subsection{Health Risk Assessment of Soil Heavy Metals}

Heavy metals and metalloid such as $\mathrm{Cr}, \mathrm{Pb}$ and As are toxic and persistently destruct human health, by the way of affecting human organs. Therefore, they are considered as the pollutants which 
lead to carcinogens [50]. The health risk assessment uses Equations (5)-(11) with the soil concentration data in surface soil $(0 \sim 20 \mathrm{~cm})$.

Three exposure routes of non-carcinogenic risks for adults and children are shown in Table 7. For non-carcinogenic risk, the hazard quotient through three pathways are in order of soil ingestion > dermal contact $>$ inhalation. The contribution of soil ingestion to the total non-carcinogenic risk (HI) is the highest among three pathways, demonstrating that soil ingestion is the major exposure pathway to human health risk. The trend of three pathways for adults was the same to children. These results in the study are the same to previous studies [51-54].

The HI value to children indicated a greater hazardous than adults, this results is similar to previous studies [55]. As shown in Figure 5, The HI values are represented in the order of $\mathrm{Cr}>\mathrm{As}>$ $\mathrm{Pb}>\mathrm{Ni}>\mathrm{Hg}>\mathrm{Cd}>\mathrm{Cu}>\mathrm{Zn}$ for both adults and children. The HI values in the study areas ranged between $6.95 \times 10^{-4}$ and $9.08 \times 10^{-1}$ for children, whereas $\mathrm{HI}$ values for adults are between $2.40 \times$ $10^{-4}$ and $2.06 \times 10^{-1}$. In general, children suffer from higher non-carcinogenic risks than adults in every way of intaking heavy metals and metalloid, indicating that children are more vulnerable to the environmental pollutions. This might be due to some behavioral characteristics of children, such as hand-to-mouth activities on soil lands [56]. There is a potential risk that the public may have an influence on non-carcinogenic if $\mathrm{HI}$ values are higher than 1 [41]. Obviously, the HI for both children and adults are far less than 1, which conforms the fact that the public around the study areas does not experience non-carcinogenic effects.

Table 7. ADD, HQ and HI value of each metal for non-carcinogenic risk.

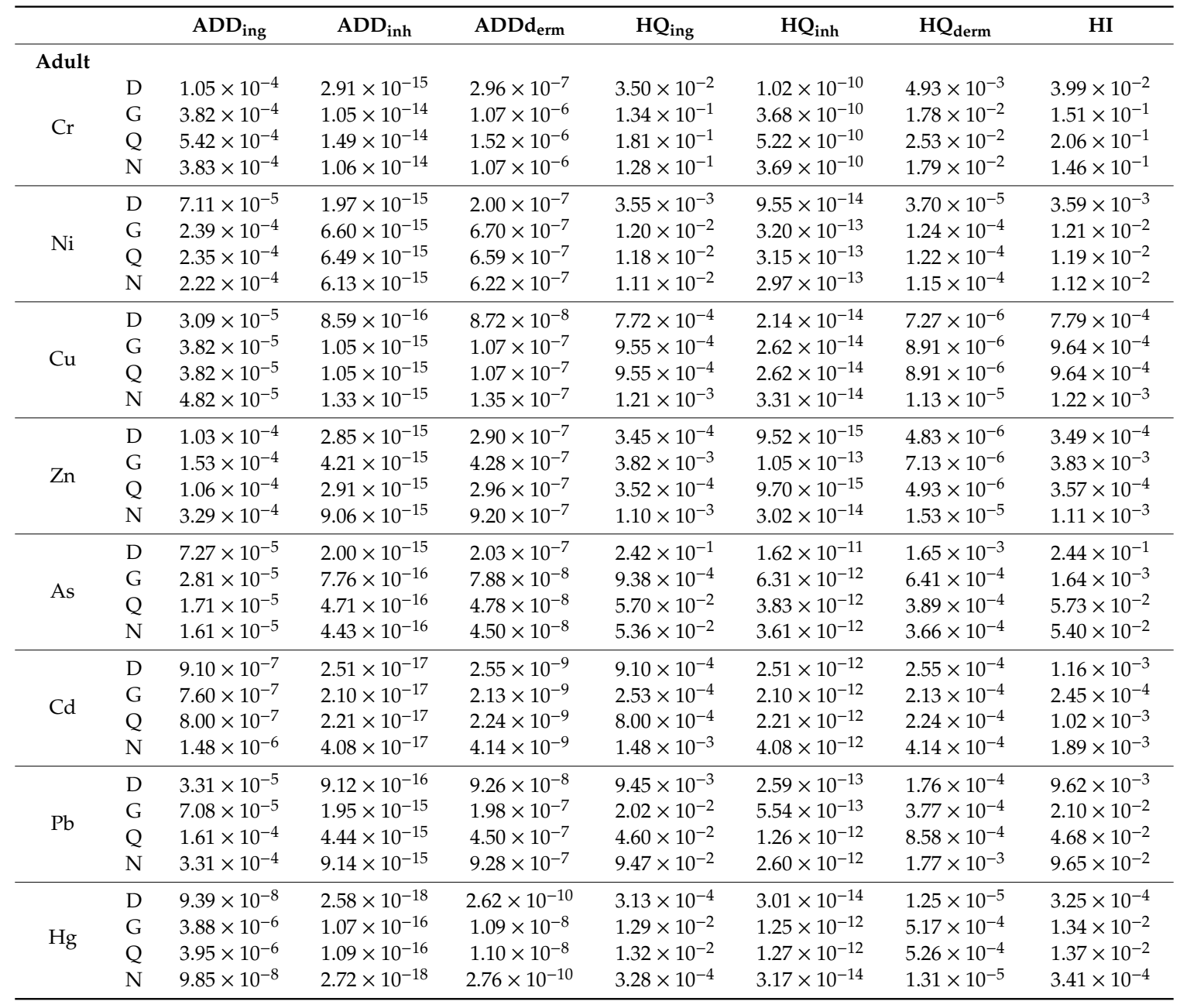


Table 7. Cont

\begin{tabular}{|c|c|c|c|c|c|c|c|c|}
\hline \multicolumn{9}{|c|}{ Children } \\
\hline \multirow{4}{*}{$\mathrm{Cr}$} & $\mathrm{D}$ & $1.77 \times 10^{-4}$ & $1.89 \times 10^{-14}$ & $7.07 \times 10^{-6}$ & $5.91 \times 10^{-1}$ & $6.61 \times 10^{-10}$ & $1.18 \times 10^{-1}$ & $1.77 \times 10^{-1}$ \\
\hline & G & $6.42 \times 10^{-4}$ & $6.69 \times 10^{-14}$ & $2.56 \times 10^{-5}$ & $2.14 \times 10^{-1}$ & $2.34 \times 10^{-9}$ & $4.27 \times 10^{-1}$ & $6.41 \times 10^{-1}$ \\
\hline & Q & $9.10 \times 10^{-4}$ & $9.49 \times 10^{-14}$ & $3.63 \times 10^{-5}$ & $6.05 \times 10^{-1}$ & $3.32 \times 10^{-9}$ & $3.03 \times 10^{-1}$ & $9.08 \times 10^{-1}$ \\
\hline & $\mathrm{N}$ & $6.43 \times 10^{-4}$ & $6.86 \times 10^{-14}$ & $2.57 \times 10^{-5}$ & $4.28 \times 10^{-1}$ & $2.40 \times 10^{-9}$ & $2.14 \times 10^{-1}$ & $6.42 \times 10^{-1}$ \\
\hline \multirow{4}{*}{$\mathrm{Ni}$} & $\mathrm{D}$ & $1.20 \times 10^{-4}$ & $1.28 \times 10^{-14}$ & $4.78 \times 10^{-6}$ & $5.99 \times 10^{-3}$ & $6.20 \times 10^{-13}$ & $8.86 \times 10^{-4}$ & $6.88 \times 10^{-3}$ \\
\hline & G & $4.02 \times 10^{-4}$ & $4.19 \times 10^{-14}$ & $1.60 \times 10^{-5}$ & $2.01 \times 10^{-2}$ & $2.03 \times 10^{-12}$ & $2.97 \times 10^{-3}$ & $2.30 \times 10^{-2}$ \\
\hline & Q & $3.95 \times 10^{-4}$ & $4.12 \times 10^{-14}$ & $1.58 \times 10^{-5}$ & $1.98 \times 10^{-2}$ & $2.00 \times 10^{-12}$ & $2.92 \times 10^{-3}$ & $2.27 \times 10^{-2}$ \\
\hline & $\hat{N}$ & $3.73 \times 10^{-4}$ & $3.98 \times 10^{-14}$ & $1.49 \times 10^{-5}$ & $1.87 \times 10^{-2}$ & $1.93 \times 10^{-12}$ & $2.76 \times 10^{-3}$ & $2.14 \times 10^{-2}$ \\
\hline \multirow{4}{*}{$\mathrm{Cu}$} & $\mathrm{D}$ & $5.23 \times 10^{-5}$ & $5.58 \times 10^{-15}$ & $2.09 \times 10^{-6}$ & $1.31 \times 10^{-3}$ & $1.39 \times 10^{-13}$ & $1.74 \times 10^{-4}$ & $1.48 \times 10^{-3}$ \\
\hline & G & $6.42 \times 10^{-5}$ & $6.69 \times 10^{-15}$ & $2.56 \times 10^{-6}$ & $1.60 \times 10^{-3}$ & $1.66 \times 10^{-13}$ & $2.13 \times 10^{-4}$ & $1.80 \times 10^{-3}$ \\
\hline & Q & $6.42 \times 10^{-5}$ & $6.69 \times 10^{-15}$ & $2.56 \times 10^{-6}$ & $1.60 \times 10^{-3}$ & $1.66 \times 10^{-13}$ & $2.13 \times 10^{-4}$ & $1.82 \times 10^{-3}$ \\
\hline & $\mathrm{N}$ & $8.10 \times 10^{-5}$ & $8.64 \times 10^{-15}$ & $3.23 \times 10^{-6}$ & $2.03 \times 10^{-3}$ & $2.15 \times 10^{-13}$ & $2.69 \times 10^{-4}$ & $2.30 \times 10^{-3}$ \\
\hline \multirow{4}{*}{$\mathrm{Zn}$} & $\mathrm{D}$ & $1.74 \times 10^{-4}$ & $1.85 \times 10^{-14}$ & $6.94 \times 10^{-6}$ & $5.80 \times 10^{-4}$ & $6.18 \times 10^{-14}$ & $1.16 \times 10^{-4}$ & $6.95 \times 10^{-4}$ \\
\hline & G & $2.57 \times 10^{-4}$ & $2.68 \times 10^{-14}$ & $1.02 \times 10^{-5}$ & $8.55 \times 10^{-4}$ & $6.66 \times 10^{-13}$ & $1.71 \times 10^{-4}$ & $1.00 \times 10^{-3}$ \\
\hline & Q & $1.77 \times 10^{-4}$ & $1.85 \times 10^{-14}$ & $7.07 \times 10^{-6}$ & $5.91 \times 10^{-4}$ & $6.16 \times 10^{-14}$ & $1.18 \times 10^{-4}$ & $7.09 \times 10^{-4}$ \\
\hline & $\hat{N}$ & $5.52 \times 10^{-4}$ & $5.89 \times 10^{-14}$ & $2.20 \times 10^{-5}$ & $1.84 \times 10^{-3}$ & $1.96 \times 10^{-13}$ & $3.67 \times 10^{-4}$ & $2.21 \times 10^{-3}$ \\
\hline \multirow{4}{*}{ As } & $\mathrm{D}$ & $1.22 \times 10^{-4}$ & $1.30 \times 10^{-14}$ & $4.85 \times 10^{-6}$ & $4.05 \times 10^{-1}$ & $1.05 \times 10^{-10}$ & $3.94 \times 10^{-2}$ & $4.45 \times 10^{-1}$ \\
\hline & G & $4.73 \times 10^{-5}$ & $4.93 \times 10^{-15}$ & $1.89 \times 10^{-6}$ & $1.58 \times 10^{-1}$ & $4.01 \times 10^{-11}$ & $1.53 \times 10^{-2}$ & $1.70 \times 10^{-1}$ \\
\hline & Q & $2.87 \times 10^{-5}$ & $2.99 \times 10^{-15}$ & $1.15 \times 10^{-6}$ & $9.57 \times 10^{-2}$ & $2.43 \times 10^{-11}$ & $9.31 \times 10^{-3}$ & $1.05 \times 10^{-1}$ \\
\hline & $\mathrm{N}$ & $2.70 \times 10^{-5}$ & $2.88 \times 10^{-15}$ & $1.08 \times 10^{-6}$ & $9.00 \times 10^{-2}$ & $2.34 \times 10^{-11}$ & $8.76 \times 10^{-3}$ & $9.88 \times 10^{-2}$ \\
\hline \multirow{4}{*}{$\mathrm{Cd}$} & $\mathrm{D}$ & $1.53 \times 10^{-6}$ & $1.63 \times 10^{-16}$ & $6.10 \times 10^{-8}$ & $6.10 \times 10^{-3}$ & $1.63 \times 10^{-11}$ & $1.53 \times 10^{-3}$ & $7.62 \times 10^{-3}$ \\
\hline & G & $1.28 \times 10^{-6}$ & $1.33 \times 10^{-16}$ & $5.09 \times 10^{-8}$ & $5.09 \times 10^{-3}$ & $1.33 \times 10^{-11}$ & $1.28 \times 10^{-3}$ & $6.41 \times 10^{-3}$ \\
\hline & Q & $1.34 \times 10^{-6}$ & $1.40 \times 10^{-16}$ & $5.36 \times 10^{-8}$ & $5.36 \times 10^{-3}$ & $1.40 \times 10^{-11}$ & $1.34 \times 10^{-3}$ & $6.71 \times 10^{-3}$ \\
\hline & $\mathrm{N}$ & $2.48 \times 10^{-6}$ & $2.65 \times 10^{-16}$ & $9.91 \times 10^{-8}$ & $9.91 \times 10^{-3}$ & $2.65 \times 10^{-11}$ & $2.48 \times 10^{-3}$ & $1.24 \times 10^{-2}$ \\
\hline \multirow{4}{*}{$\mathrm{Pb}$} & $\mathrm{D}$ & $5.55 \times 10^{-5}$ & $5.92 \times 10^{-15}$ & $2.22 \times 10^{-6}$ & $1.59 \times 10^{-2}$ & $1.68 \times 10^{-12}$ & $4.22 \times 10^{-3}$ & $2.01 \times 10^{-2}$ \\
\hline & G & $1.19 \times 10^{-4}$ & $1.24 \times 10^{-14}$ & $4.74 \times 10^{-6}$ & $3.40 \times 10^{-2}$ & $3.52 \times 10^{-12}$ & $9.03 \times 10^{-3}$ & $4.32 \times 10^{-2}$ \\
\hline & $\mathrm{Q}$ & $2.70 \times 10^{-4}$ & $2.82 \times 10^{-14}$ & $1.08 \times 10^{-5}$ & $7.72 \times 10^{-2}$ & $8.01 \times 10^{-12}$ & $2.05 \times 10^{-2}$ & $9.77 \times 10^{-2}$ \\
\hline & $\hat{\mathrm{N}}$ & $5.57 \times 10^{-4}$ & $5.93 \times 10^{-14}$ & $2.22 \times 10^{-5}$ & $1.59 \times 10^{-1}$ & $1.69 \times 10^{-11}$ & $4.23 \times 10^{-2}$ & $2.01 \times 10^{-1}$ \\
\hline \multirow{4}{*}{$\mathrm{Hg}$} & $\mathrm{D}$ & $1.57 \times 10^{-7}$ & $1.67 \times 10^{-17}$ & $6.26 \times 10^{-9}$ & $5.23 \times 10^{-4}$ & $1.95 \times 10^{-13}$ & $2.98 \times 10^{-4}$ & $8.22 \times 10^{-4}$ \\
\hline & G & $6.51 \times 10^{-6}$ & $6.79 \times 10^{-16}$ & $2.60 \times 10^{-7}$ & $2.17 \times 10^{-2}$ & $7.93 \times 10^{-12}$ & $1.24 \times 10^{-2}$ & $3.42 \times 10^{-2}$ \\
\hline & Q & $6.63 \times 10^{-6}$ & $6.91 \times 10^{-16}$ & $2.64 \times 10^{-7}$ & $2.21 \times 10^{-2}$ & $8.07 \times 10^{-12}$ & $1.26 \times 10^{-2}$ & $3.47 \times 10^{-2}$ \\
\hline & $\mathrm{N}$ & $1.65 \times 10^{-7}$ & $1.76 \times 10^{-17}$ & $6.60 \times 10^{-9}$ & $5.51 \times 10^{-4}$ & $2.06 \times 10^{-13}$ & $3.14 \times 10^{-4}$ & $8.66 \times 10^{-4}$ \\
\hline
\end{tabular}

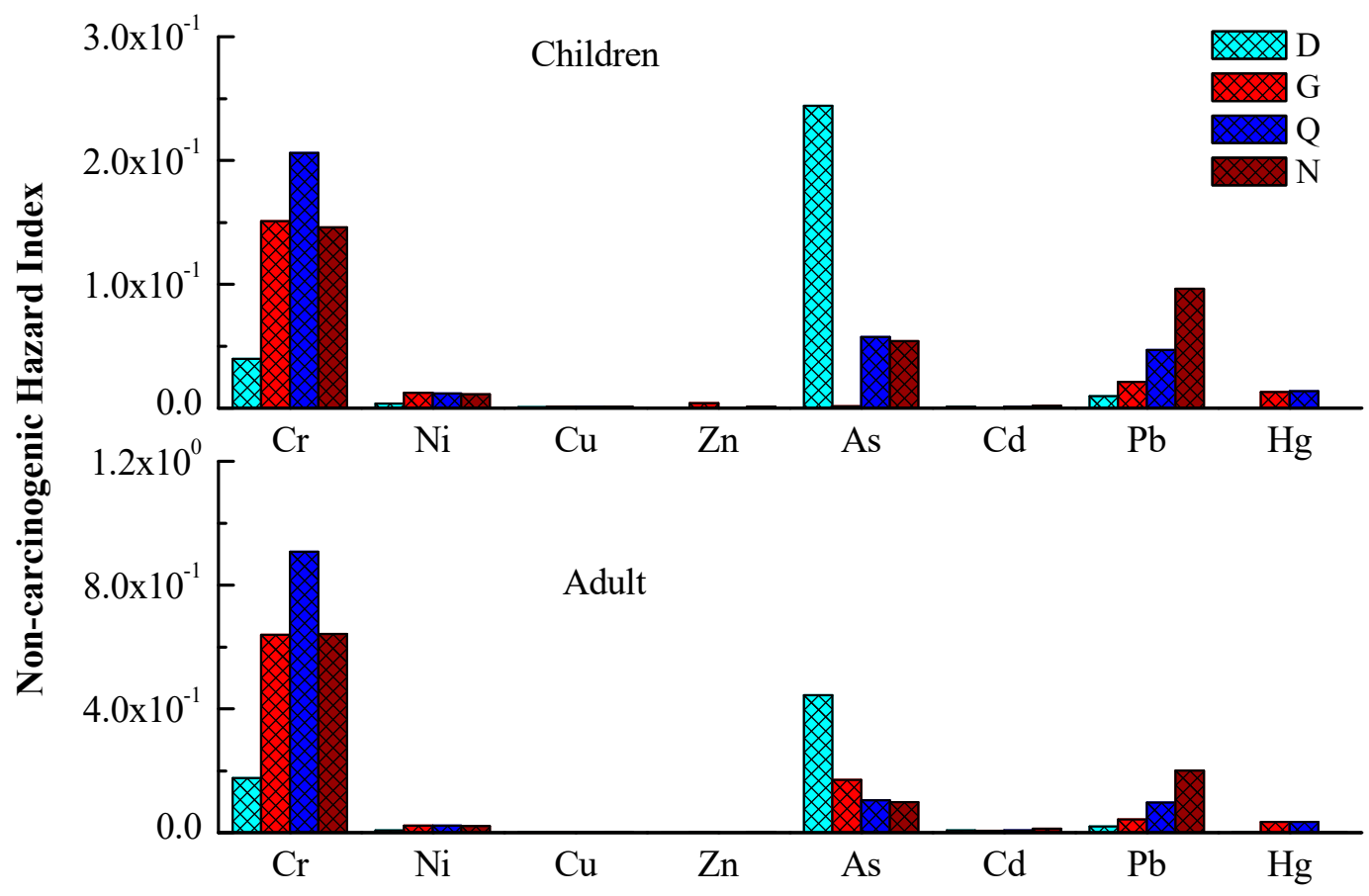

Figure 5. Non-carcinogenic risk for adults and children. 
Additionally, the carcinogenic risk values for children and adults are illustrated in Table 8 and Figure $6 . \mathrm{Hg}, \mathrm{Pb}, \mathrm{Cu}$ and $\mathrm{Ni}$ are not presented due to there were no carcinogenic slope factor for them. The trend of LCR is similar to HI values. The carcinogenic risk decreases as follow: soil ingestion $>$ dermal contact $>$ soil inhalation. As, $\mathrm{Pb}$, and $\mathrm{Cr}$ presented a greater carcinogenic risk for both children and adults, and the LCR values for $\mathrm{Cr}$ are between $9.22 \times 10^{-5}$ and $4.73 \times 10^{-4}$ (for children) and between $5.26 \times 10^{-5}$ and $2.72 \times 10^{-4}$ (for adults). It was found that besides $\mathrm{Cr}$, the rest of three elements almost stood in the range of acceptable risk $\left(1 \times 10^{-6}-1 \times 10^{-4}\right)$ [57]. The $\mathrm{LCR}$ values of $\mathrm{Cr}$ for children in $\mathrm{G}, \mathrm{Q}$ and $\mathrm{N}$ were 3.34, 4.73, 3.34 times higher than the max tolerable risk, respectively. Similarly, the LCR of Cr for adults in G, Q and N were 1.92, 2.72, 1.92 times of the max tolerable risk, suggesting that there was carcinogenic risk of $\mathrm{Cr}$ in study areas. The results are similar to Liu et al. [58] in coal mining city.

Table 8. Carcinogenic risks for different exposure pathways for adults and children.

\begin{tabular}{|c|c|c|c|c|c|}
\hline \multicolumn{6}{|c|}{ Children } \\
\hline Metal Element & Site & $C R_{\text {Ing }}$ & $C R_{I n h}$ & $C R_{\text {derm }}$ & LCR (HI) \\
\hline \multirow{4}{*}{$\mathrm{Cr}$} & $\mathrm{D}$ & $8.86 \times 10^{-5}$ & $9.45 \times 10^{-15}$ & $3.54 \times 10^{-6}$ & $9.22 \times 10^{-5}$ \\
\hline & G & $3.21 \times 10^{-4}$ & $3.35 \times 10^{-14}$ & $1.28 \times 10^{-5}$ & $3.34 \times 10^{-4}$ \\
\hline & Q & $4.55 \times 10^{-4}$ & $4.75 \times 10^{-14}$ & $1.82 \times 10^{-5}$ & $4.73 \times 10^{-4}$ \\
\hline & $\mathrm{N}$ & $3.22 \times 10^{-4}$ & $3.43 \times 10^{-14}$ & $1.28 \times 10^{-5}$ & $3.34 \times 10^{-4}$ \\
\hline \multirow{4}{*}{ As } & $\mathrm{D}$ & $1.82 \times 10^{-5}$ & $1.94 \times 10^{-14}$ & $7.27 \times 10^{-6}$ & $1.90 \times 10^{-5}$ \\
\hline & G & $7.09 \times 10^{-5}$ & $7.40 \times 10^{-15}$ & $2.83 \times 10^{-6}$ & $7.37 \times 10^{-5}$ \\
\hline & Q & $4.30 \times 10^{-5}$ & $4.49 \times 10^{-15}$ & $1.72 \times 10^{-6}$ & $4.48 \times 10^{-5}$ \\
\hline & $\hat{\mathrm{N}}$ & $4.05 \times 10^{-5}$ & $4.32 \times 10^{-15}$ & $1.62 \times 10^{-6}$ & $4.21 \times 10^{-5}$ \\
\hline \multirow{4}{*}{$\mathrm{Cd}$} & $\mathrm{D}$ & $9.63 \times 10^{-6}$ & $1.03 \times 10^{-15}$ & $3.84 \times 10^{-7}$ & $1.00 \times 10^{-5}$ \\
\hline & G & $8.04 \times 10^{-6}$ & $8.39 \times 10^{-16}$ & $3.21 \times 10^{-7}$ & $8.36 \times 10^{-6}$ \\
\hline & Q & $8.47 \times 10^{-6}$ & $8.83 \times 10^{-16}$ & $3.38 \times 10^{-7}$ & $8.80 \times 10^{-6}$ \\
\hline & $\mathrm{N}$ & $1.56 \times 10^{-5}$ & $1.67 \times 10^{-15}$ & $6.24 \times 10^{-7}$ & $1.63 \times 10^{-5}$ \\
\hline \multirow{4}{*}{$\mathrm{Pb}$} & $\mathrm{D}$ & $4.72 \times 10^{-6}$ & $5.03 \times 10^{-16}$ & $1.88 \times 10^{-7}$ & $4.91 \times 10^{-6}$ \\
\hline & G & $1.01 \times 10^{-5}$ & $1.05 \times 10^{-15}$ & $4.03 \times 10^{-7}$ & $1.05 \times 10^{-5}$ \\
\hline & Q & $2.30 \times 10^{-5}$ & $2.40 \times 10^{-15}$ & $9.16 \times 10^{-7}$ & $2.39 \times 10^{-5}$ \\
\hline & $\mathrm{N}$ & $4.73 \times 10^{-5}$ & $5.04 \times 10^{-15}$ & $1.89 \times 10^{-6}$ & $4.92 \times 10^{-5}$ \\
\hline \multicolumn{6}{|c|}{ Adults } \\
\hline Metal Element & Site & $C R_{\text {Ing }}$ & $C R_{I n h}$ & $C R_{\text {derm }}$ & LCR (HI) \\
\hline \multirow{4}{*}{$\mathrm{Cr}$} & $\mathrm{D}$ & $5.25 \times 10^{-5}$ & $1.46 \times 10^{-15}$ & $1.48 \times 10^{-7}$ & $5.26 \times 10^{-5}$ \\
\hline & G & $1.91 \times 10^{-4}$ & $5.27 \times 10^{-15}$ & $5.35 \times 10^{-7}$ & $1.92 \times 10^{-4}$ \\
\hline & Q & $2.71 \times 10^{-4}$ & $7.47 \times 10^{-15}$ & $7.58 \times 10^{-7}$ & $2.72 \times 10^{-4}$ \\
\hline & $\tilde{N}$ & $1.91 \times 10^{-4}$ & $5.28 \times 10^{-15}$ & $5.36 \times 10^{-7}$ & $1.92 \times 10^{-4}$ \\
\hline \multirow{4}{*}{ As } & $\mathrm{D}$ & $1.09 \times 10^{-5}$ & $2.99 \times 10^{-15}$ & $3.04 \times 10^{-7}$ & $1.09 \times 10^{-5}$ \\
\hline & G & $4.22 \times 10^{-5}$ & $1.16 \times 10^{-15}$ & $1.18 \times 10^{-7}$ & $4.23 \times 10^{-5}$ \\
\hline & Q & $2.56 \times 10^{-5}$ & $7.07 \times 10^{-16}$ & $7.18 \times 10^{-8}$ & $2.57 \times 10^{-5}$ \\
\hline & $\tilde{N}$ & $2.41 \times 10^{-5}$ & $6.65 \times 10^{-16}$ & $6.75 \times 10^{-8}$ & $2.42 \times 10^{-5}$ \\
\hline \multirow{4}{*}{$\mathrm{Cd}$} & $\mathrm{D}$ & $5.73 \times 10^{-6}$ & $1.58 \times 10^{-16}$ & $1.60 \times 10^{-8}$ & $5.75 \times 10^{-6}$ \\
\hline & G & $4.79 \times 10^{-6}$ & $1.32 \times 10^{-16}$ & $1.34 \times 10^{-8}$ & $4.80 \times 10^{-6}$ \\
\hline & Q & $5.04 \times 10^{-6}$ & $1.39 \times 10^{-16}$ & $1.41 \times 10^{-8}$ & $5.05 \times 10^{-6}$ \\
\hline & $\mathrm{N}$ & $9.31 \times 10^{-6}$ & $2.57 \times 10^{-16}$ & $2.61 \times 10^{-8}$ & $9.34 \times 10^{-6}$ \\
\hline \multirow{4}{*}{$\mathrm{Pb}$} & $\mathrm{D}$ & $2.81 \times 10^{-6}$ & $7.75 \times 10^{-17}$ & $7.87 \times 10^{-9}$ & $2.82 \times 10^{-6}$ \\
\hline & G & $6.01 \times 10^{-6}$ & $1.66 \times 10^{-16}$ & $1.68 \times 10^{-8}$ & $6.03 \times 10^{-6}$ \\
\hline & Q & $1.37 \times 10^{-5}$ & $3.77 \times 10^{-16}$ & $3.83 \times 10^{-8}$ & $1.37 \times 10^{-5}$ \\
\hline & $\mathrm{N}$ & $2.82 \times 10^{-5}$ & $7.77 \times 10^{-16}$ & $7.89 \times 10^{-8}$ & $2.82 \times 10^{-5}$ \\
\hline
\end{tabular}




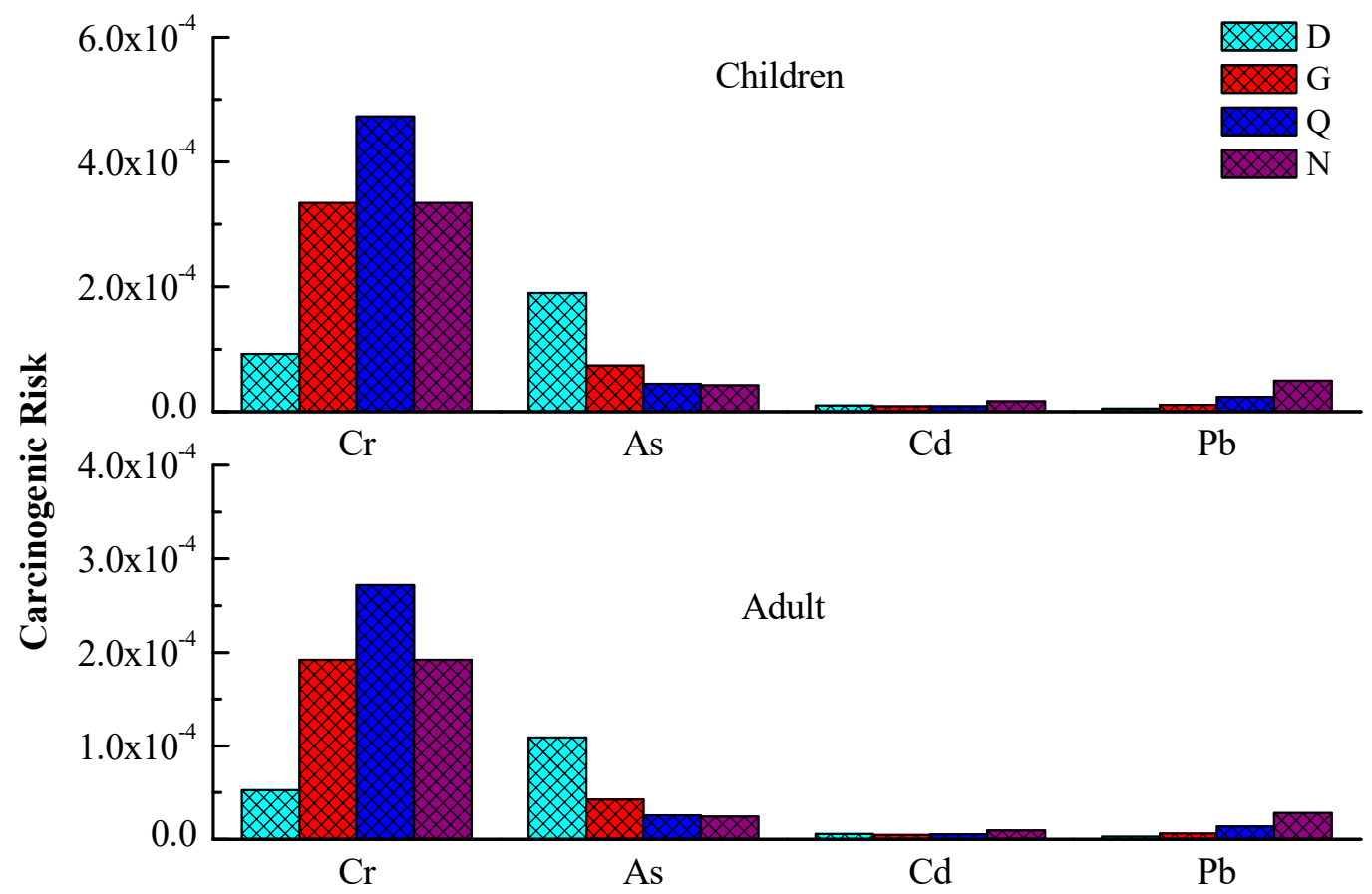

Figure 6. Carcinogenic risk for adults and children.

\section{Conclusions}

In the paper, the concentrations, geo-accumulation index, PER and HRA of heavy metals and metalloid in Xunyang mining areas are demonstrated. The mean concentration of heavy metals and metalloid of As and $\mathrm{Cd}$ in $\mathrm{D} ; \mathrm{Cr}, \mathrm{Ni}, \mathrm{Cd}$, and $\mathrm{Hg}$ in $\mathrm{G}$ and $\mathrm{Q} . \mathrm{Cr}, \mathrm{Ni}, \mathrm{Zn}, \mathrm{Cd}$ and $\mathrm{Pb}$ in $\mathrm{N}$ were found that have exceeded the standard values.

The $I_{G e o}$ values have proved that the soils were contaminated with most heavy metals at some locations. Especially, Hg extremely contaminated the soils at G and Q. The results of PER analysis showed that the RI range of the PER assessment indexes in the study areas are between 134.54 and 2667.19, and the RI values in G and Q showed the significantly high risk due to the great portion of $\mathrm{Hg}$. HRA demonstrated that HI values were higher among children than adults both for carcinogenic and non-carcinogenic risks. The results showed that human health risk is mainly caused by soil ingestion in study areas, the non-carcinogenic risks for both children and adults are within acceptable limits. However, the value of carcinogenic risk on $\mathrm{Cr}$ exceeded the tolerance limit for both adults and children, suggesting that $\mathrm{Cr}$ has a notable risk to human health.

Heavy metals and metalloid do not only harm human through soil, but also via water and atmosphere, but in this study, only the mining area heavy metals and metalloid in soil are analyzed. In the future study, the water and the atmosphere in the vicinity of mining areas will also be investigated.

Author Contributions: Formal analysis, N.W. and Y.S.; Investigation, G.L. and Y.W.; Methodology, N.W.; Writing-Original Draft, N.W.; Writing—review and editing, N.W., Y.W. and J.H.

Funding: Financial support was provided by the Fundamental Research Funds for the Central University (No. 300102278503).

Conflicts of Interest: The authors declare no conflict of interest.

\section{References}

1. Chen, Y.Z.; Yang, H.; Zhang, Z.K.; Qin, M.Z.; Jin, F.; Lu, J.J. Application of Equilibrium Partitioning Approach to the Derivation of Sediment Quality Guidelines for Metals in Dianchi Lake. Pedosphere 2007, 17, 284-294. [CrossRef] 
2. Zhu, D.; Wei, Y.; Zhao, Y.; Wang, Q.; Han, J. Heavy Metal pollution and ecological risk assessment of the agriculture soil in Xunyang Mining Area, Shaanxi Province, Northwestern China. Bull. Environ. Contam. Toxicol. 2018, 101, 178-184. [CrossRef] [PubMed]

3. Ministry of Environmental Protection of the People's Republic of China (MEPPRC). Bulletin on National Survey of Soil Contamination; Ministry of Environmental Protection of the People's Republic of China: Beijing, China, 2014. (In Chinese)

4. Xiao, R.; Wang, S.; Li, R.; Wang, J.J.; Zhang, Z. Soil heavy metal contamination and health risks associated with artisanal gold mining in Tongguan, Shaanxi, China. Ecotoxicol. Environ. Saf. 2017, 141, 17-24. [CrossRef] [PubMed]

5. Abad-Valle, P.; Álvarez-Ayuso, E.; Murciego, A.; Pellitero, E. Assessment of the use of sepiolite amendment to restore heavy metal polluted mine soil. Geoderma 2016, 280, 57-66. [CrossRef]

6. Acosta, J.A.; Faz, A.; Martinez-Martinez, S.; Zornoza, R.; Carmona, D.M.; Kabas, S. Multivariate statistical and GIS-based approach to evaluate heavy metals behaviour in mine sites for future reclamation. J. Geochem. Explor. 2011, 109, 8-17. [CrossRef]

7. Navarro, M.; Pérez-Sirvent, C.; Martínez-Sánchez, M.; Vidal, J.; Tovar, P.; Bech, J. Abandoned mine sites as a source of contamination by heavy metals: A case study in a semi-arid zone. J. Geochem. Explor. 2008, 96, 183-193. [CrossRef]

8. Akar, T.; Tunali, S. Biosorption performance of Botrytis cinerea fungal by-products for removal of Cd(II) and $\mathrm{Cu}(\mathrm{II})$ ions from aqueous solutions. Miner. Eng. 2005, 18, 1099-1109. [CrossRef]

9. Zhuang, P.; Zou, B.; Li, N.Y.; Li, Z.A. Heavy metal contamination in soils and food crops around Dabaoshan mine in Guangdong, China: Implication for human health. Environ. Geochem. Health 2009, 31, 707-715. [CrossRef]

10. Obeng-Gyasi, E. Sources of lead exposure in various countries. Rev. Environ. Health 2019, 34, 25-34. [CrossRef]

11. Garelick, H.; Jones, H.; Dybowska, A.; Valsamijones, E. Arsenic Pollution Sources. Rev. Environ. Contam. Toxicol. 2008, 197, 17-60.

12. Giaccio, L.; Cicchella, D.; De Vivo, B.; Lombardi, G.; De Rosa, M. Does heavy metals pollution affects semen quality in men? A case of study in the metropolitan area of Naples (Italy). J. Geochem. Explor. 2012, 112, 218-225. [CrossRef]

13. Olawoyin, R.; Oyewole, S.A.; Grayson, R.L. Potential risk effect from elevated levels of soil heavy metals on human health in the Niger delta. Ecotoxicol. Environ. Saf. 2012, 85, 120-130. [CrossRef] [PubMed]

14. Järup, L. Hazards of heavy metal contamination. Br. Med. Bull. 2003, 68, 167-182. [CrossRef] [PubMed]

15. Gulson, B.; Jameson, C.; Mahaffey, K.; Mizon, K.; Korsch, M.; Vimpani, G. Pregnancy increases mobilization of lead from maternal skeleton. J. Lab. Clin. Med. 1997, 130, 51-62. [CrossRef]

16. Hu, H.; Tellez-Rojo, M.M.; Bellinger, D.; Smith, D.; Ettinger, A.S.; Lamadrid-Figueroa, H.; Schwartz, J.; Schnaas, L.; Mercado-García, A.; Hernandez-Avila, M. Fetal Lead Exposure at Each Stage of Pregnancy as a Predictor of Infant Mental Development. Environ. Health Perspect. 2006, 114, 1730-1735. [CrossRef] [PubMed]

17. Reuben, A.; Caspi, A.; Belsky, D.W.; Broadbent, J.; Harrington, H.; Sugden, K.; Houts, R.M.; Ramrakha, S.; Poulton, R.; Moffitt, T.E. Association of childhood blood-lead levels with cognitive function and socioeconomic status at age 38 years and with IQ change and socioeconomic mobility between childhood and adulthood. JAMA 2017, 317, 1244-1251. [CrossRef] [PubMed]

18. Lanphear, B.P.; Rauch, S.; Auinger, P.; Allen, R.W.; Hornung, R.W. Low-level lead exposure and mortality in US adults: A population-based cohort study. Lancet Public Health 2018, 3, e177-e184. [CrossRef]

19. Obeng-Gyasi, E.; Armijos, R.X.; Weigel, M.M.; Filippelli, G.M.; Sayegh, M.A. Cardiovascular-Related Outcomes in U.S. Adults Exposed to Lead. Int. J. Environ. Res. Public Health 2018, 15, 759. [CrossRef] [PubMed]

20. Harari, F.; Sallsten, G.; Christensson, A.; Petkovic, M.; Hedblad, B.; Forsgard, N.; Melander, O.; Nilsson, P.M.; Borné, Y.; Engström, G.; et al. Blood Lead Levels and Decreased Kidney Function in a Population-Based Cohort. Am. J. Kidney Dis. 2018, 72, 381-389. [CrossRef] [PubMed]

21. Lin-Tan, D.T.; Yu, C.C.; Lin, J.L.; Hsu, K.H. Environmental Lead Exposure and Progression of Chronic Renal Diseases in Patients without Diabetes. N. Engl. J. Med. 2003, 348, 277-286. [CrossRef] [PubMed] 
22. Can, S.; Bagci, C.; Ozaslan, M.; Bozkurt, A.I.; Cengiz, B.; Cakmak, E.A.; Tarakçioglu, M. Occupational lead exposure effecton liver functions and biochemical parameters. Acta Physiol. Hung. 2008, 95, $395-403$. [CrossRef] [PubMed]

23. Driscoll, C.T.; Mason, R.P.; Chan, H.M.; Jacob, D.J.; Pirrone, N. Mercury as a Global Pollutant: Sources, Pathways, and Effects. Environ. Sci. Technol. 2013, 47, 4967-4983. [CrossRef] [PubMed]

24. Li, Z.; Ma, Z.; van der Kuijp, T.J.; Yuan, Z.; Huang, L. A review of soil heavy metal pollution from mines in China: Pollution and health risk assessment. Sci. Total Environ. 2014, 468, 843-853. [CrossRef] [PubMed]

25. Wu, Y.G.; Xu, Y.N.; Zhang, J.H.; Hu, S.H. Evaluation of ecological risk and primary empirical research on heavy metals in polluted soil over Xiaoqinling gold mining region, Shaanxi, China. Trans. Nonferrous Met. Soc. China 2010, 20, 688-694. [CrossRef]

26. Li, Y.; Wang, H.; Wang, H.; Yin, F.; Yang, X.; Hu, Y. Heavy metal pollution in vegetables grown in the vicinity of a multi-metal mining area in Gejiu, China: Total concentrations, speciation analysis, and health risk. Environ. Sci. Pollut. Res. 2014, 21, 12569-12582. [CrossRef] [PubMed]

27. Zhao, R.X.; Guo, W.; Sun, W.H.; Xue, S.L.; Gao, B.; Sun, W. Distribution Characteristic and Assessment of Soil Heavy Metal Pollution around Baotou Tailings in Inner Mongolia, China. Trans. Tech. Publ. 2012, 356, 2730-2736. [CrossRef]

28. Zhang, L.; Jin, Y.; Lu, J.; Zhang, C. Concentration, distribution and bioaccumulation of mercury in the Xunyang mercury mining area, Shaanxi Province, China. Appl. Geochem. 2009, 24, 950-956. [CrossRef]

29. Qiu, G.; Feng, X.; Meng, B.; Sommar, J.; Gu, C. Environmental geochemistry of an active Hg mine in Xunyang, Shaanxi Province, China. Appl. Geochem. 2012, 27, 2280-2288. [CrossRef]

30. Chen, Y.Y.; Wang, J.; Gao, W.; Sun, X.J.; Xu, S.Y. Comprehensive analysis of heavy metals in soils from Baoshan District, Shanghai: A heavily industrialized area in China. Environ. Earth Sci. 2012, 67, 2331-2343. [CrossRef]

31. Environmental Protection Agency (USEPA). Acid Digestion of Sludges, Solids and Soils. Available online: https://www.epa.gov/sites/production/files/2015-06/documents/epa-3050b.pdf (accessed on 19 February 2017).

32. Lin, C.; He, M.; Zhou, Y.; Guo, W.; Yang, Z. Distribution and contamination assessment of heavy metals in sediment of the Second Songhua River, China. Environ. Monit. Assess. 2008, 137, 329-342. [CrossRef]

33. Kusin, F.M.; Azani, N.N.M.; Hasan, S.N.M.S.; Sulong, N.A. Distribution of heavy metals and metalloid in surface sediments of heavily-mined area for bauxite ore in Pengerang, Malaysia and associated risk assessment. Catena 2018, 165, 454-464. [CrossRef]

34. Zhao, L.; Hu, Y.M.; Zhou, W.; Liu, Z.H.; Pan, Y.C.; Shi, Z.; Wang, L.; Wang, G.X. Estimation Methods for Soil Mercury Content Using Hyperspectral Remote Sensing. Sustainability 2018, 10, 2474. [CrossRef]

35. Lu, S.; Wang, Y.; Teng, Y.; Yu, X. Heavy metal pollution and ecological risk assessment of the paddy soils near a zinc-Lead mining area in Human. Environ. Monit. Assess. 2015, 187, 627. [CrossRef] [PubMed]

36. Hakanson, L. An ecological risk index for aquatic pollution control: A sediment ecological approach. Water Res. 1980, 14, 975-1001. [CrossRef]

37. Douay, F.; Pelfrêne, A.; Planque, J.; Fourrier, H.; Richard, A.; Roussel, H.; Girondelot, B. Assessment of potential health risk for inhabitants living near a former lead smelter, part 1: Metal concentrations in soils, agricultural crops, and homegrown vegetables. Environ. Monit. Assess. 2013, 185, 3665-3680. [CrossRef] [PubMed]

38. Luo, X.S.; Ding, J.; Xu, B.; Wang, Y.J.; Li, H.B.; Yu, S. Incorporating bioaccessibility into human health risk assessments of heavy metals in urban park soils. Sci. Total Environ. 2012, 424, 88-96. [CrossRef] [PubMed]

39. Gu, Y.G.; Gao, Y.P.; Lin, Q. Contamination, bioaccessibility and human health risk of heavy metals in exposed-lawn soils from 28 urban parks in southern China's largest city, Guangzhou. Appl. Geochem. 2016, 67, 52-58. [CrossRef]

40. US Environmental Protection Agency (USEPA). Integrated Risk Information System of the US Environmental Protection Agency; US Environmental Protection Agency (USEPA): Washington, DC, USA, 2012.

41. US Environmental Protection Agency (USEPA). Supplemental Guidance for Developing Soil Screening Levels for Superfund Sites, OSWER 9355; Office of Emergency and Remedial Response: Washington, DC, USA, 2002.

42. Yuswir, N.S.; Praveena, S.M.; Aris, A.Z.; Ismail, S.N.S.; Hashim, Z. Health Risk Assessment of Heavy Metal in Urban Surface Soil (Klang District, Malaysia). Bull. Environ. Contam. Toxicol. 2015, 95, 80-89. [CrossRef] [PubMed] 
43. Taylor, D. An outline of the geology of the Bukit Ibam orebody, Rompin, Pahang. Bull. Geol. Soc. Malays. 1971, 4, 71-89. [CrossRef]

44. Benhaddya, M.L.; Hadjel, M. Spatial distribution and contamination assessment of heavy metals in surface soils of Hassi Messaoud, Algeria. Environ. Earth Sci. 2014, 71, 1473-1486. [CrossRef]

45. Fantozzi, L.; Ferrara, R.; Dini, F.; Tamburello, L.; Pirrone, N.; Sprovieri, F. Study on the reduction of atmospheric mercury emissions from mine waste enriched soils through native grass cover in the Mt. Amiata region of Italy. Environ. Res. 2013, 125, 69-74. [CrossRef] [PubMed]

46. Gray, J.E.; Theodorakos, P.M.; Fey, D.L.; Krabbenhoft, D.P. Mercury concentrations and distribution in soil, water, mine waste leachates, and air in and around mercury mines in the Big Bend region, Texas, USA. Environ. Geochem. Health 2015, 37, 35-48. [CrossRef]

47. Tarras-Wahlberg, N. Environmental management of small-scale and artisanal mining: The Portovelo-Zaruma goldmining area, southern Ecuador. J. Environ. Manag. 2002, 65, 165-179. [CrossRef]

48. Burges, A.; Epelde, L.; Garbisu, C. Impact of repeated single-metal and multimetal pollution events on soil quality. Chemosphere 2015, 120, 8-15. [CrossRef] [PubMed]

49. Xu, Z.Q.; Ni, S.J.; Tuo, X.G.; Zhang, C.J. Calculation of heavy metals' toxicity coefficient in the evaluation of potential ecological risk index. Environ. Sci. Technol. 2008, 31, 112-115.

50. Liu, S.J.; Jiang, J.Y.; Wang, S.; Guo, Y.P.; Ding, H. Assessment of water-soluble thiourea-formaldehyde (WTF) resin for stabilization/solidification (S/S) of heavy metal contaminated soils. J. Hazard. Mater. 2018, 346, 167-173. [CrossRef] [PubMed]

51. Chabukdhara, M.; Nema, A.K. Heavy metals assessment in urban soil around industrial clusters in Ghaziabad, India: Probabilistic health risk approach. Ecotoxicol. Environ. Saf. 2013, 87, 57-64. [CrossRef] [PubMed]

52. Chen, H.; Teng, Y.; Lu, S.; Wang, Y.; Wu, J.; Wang, J. Source apportionment and health risk assessment of trace metals in surface soils of Beijing metropolitan, China. Chemosphere 2016, 144, 1002-1011. [CrossRef] [PubMed]

53. Xiao, Q.; Zong, Y.; Lu, S. Assessment of heavy metal pollution and human health risk in urban soils of steel industrial city (Anshan), Liaoning, Northeast China. Ecotox. Environ. Saf. 2015, 120, 377-385.

54. Yang, J.; Chen, T.; Lu, L.; Tang, Y. In Vitro Health Risk Assessment of Ingesting Metal-Enriched Soils and Dusts in a Chinese Mining City. Hum. Ecol. Risk Assess. Int. J. 2015, 21, 1-17. [CrossRef]

55. Diami, S.M.; Kusin, F.M.; Madzin, Z. Potential ecological and human health risks of heavy metals in surface soils associated with iron ore mining in Pahang, Malaysia. Environ. Sci. Pollut. Res. 2016, 23, 21086-21097. [CrossRef] [PubMed]

56. Jiang, Y.; Chao, S.; Zhang, A.; Cao, H.; Liu, J.; Yang, Y.; Chen, Y. Source apportionment and health risk assessment of heavy metals in soil for a township in Jiangsu Province, China. Chemosphere 2017, 168, 1658-1668. [CrossRef] [PubMed]

57. Fryer, M.; Collins, C.D.; Ferrier, H.; Colvile, R.N.; Nieuwenhuijsen, M.J. Human exposure modelling for chemical risk assessment: A review of current approaches and research and policy implications. Environ. Sci. Policy 2006, 9, 261-274. [CrossRef]

58. Ying, L.; Lei, S.; Chen, X. Assessment of heavy metal pollution and human health risk in urban soils of the coal mining city, Huainan, East China. Hum. Ecol. Risk Assess. Int. J. 2016, 22, 1359-1374. [CrossRef]

(C) 2019 by the authors. Licensee MDPI, Basel, Switzerland. This article is an open access article distributed under the terms and conditions of the Creative Commons Attribution (CC BY) license (http://creativecommons.org/licenses/by/4.0/). 